\title{
Study of Production and Productivity of Sago Plant in East Kolaka District, Southeast Sulawesi Province, Indonesia
}

\author{
Asthutiirundu ${ }^{1.2}$, Sitti Bulkis ${ }^{3}$, Imam Mujahidin ${ }^{3}$, M. H. Jamil ${ }^{3}$ \\ ${ }^{1}$ Doctoral Program, Post Graduate School, Hasanuddin University, Makassar, Makassar, South Celebes, \\ Indonesia \\ ${ }^{2}$ Palmae Research Institution, Manado, Manado, North Celebes, Indonesia \\ ${ }^{3}$ Social and Economic of Agriculture Departement, Agriculture Faculty, Hasanuddin University, Makassar, \\ Makassar, South Celebes, Indonesia \\ Correspondent email : asthutiirundu@yahoo.co.id
}

\begin{abstract}
Optimal utilization of sago plants can provide large incomes to farm households. Generally in Indonesia sago is only used as a staple food for the daily life of the family as a companion to rice. However, some region in Indonesia uses sago as the main staple food source, such as in Maluku, Papua, parts of Sulawesi such as East Kolaka. The purpose of this study is to examine in depth the production and productivity of sago plants in the East Kolaka Regency. The study was conducted in the East Kolaka Regency of Southeast Sulawesi Province in 2018. The respondents of this study were 203 sago farmers. The study uses a quantitative approach with a combination of survey methods with quantitative and qualitative descriptive data analysis. The results showed that sago production in East Kalimantan in each year ranged from 119 sacks/ year - 363 sacks/ year or equivalent to $2,161 \mathrm{~kg} / \mathrm{yr}-6,606 \mathrm{~kg} / \mathrm{yr}$. The highest average sago starch production is in the Poniponiki village, which is $6,606 \mathrm{~kg} / \mathrm{yr}$. While the lowest production is in the Ladongi village, 2,161 kg/ yr. The highest productivity was found in Alaaha village, which was 7.7 tons /ha/ yr while the lowest productivity was 2.5 tons /ha/ yr in Ladongi village. Sago plant productivity in East Kalimantan shows quite good productivity for the condition of sago cultivation that is still extractive tautology. This shows that when sago plantations are used in the improvement of sago plant technology in East Kalimantan, they will provide productivity far higher than current production.
\end{abstract}

Keywords : Sago, Pattern, Production, Farmer

\section{INTRODUCTION}

Currently, sago has been used as a variety of products that are beneficial to humans, especially widely used in vermicelli and noodle industries (Joy, 2018). Sago is not only in demand by sago-producing regions but is starting to be in demand by various groups because of the many benefits provided by sago. Sago is one of the commercially valued plants if used optimally. The commercial value can be obtained when sago becomes modified flour and ethanol instead of petroleum and natural gas (Singhal et al., 2008: 1; Bintoro et al., 2010: 1; Syakir and Karmawati, 2013; 57), noodles from sago (Haryanto and Henanto, 2003: 156), biodegradable plastic for various types of pharmaceutical, cosmetic and food product packaging (Barlina and Karouw, 2003: 105), Sago waste can be used as a medium for microorganism growth (Juwita 
et al., 2013: 35 ) including in producing glucose (Suriani, 2002: 526), besides that sago is used as raw material in vermicelli factories (Taridala et al., 2013: 7).

Furthermore, the current use of sago is not only limited to food for humans but now sago can also be processed into raw material for animal feed and fish (Bintoro et al., 2010: 1). Also, sago plants can protect people from the dangers of flooding because sago has a function of a buffer zone for flooding (Ibrahim and Gunawan, 2015: 1). On the other hand, people use other parts of sago plants to be used as building materials such as sago leaves as roofs, sago fronds can be used to make walls of houses and seats (Ruhukail, 2012: 65).

Sago is one of the sources of livelihoods in several regions (Nguyen et al., 2017: 1) which provides income and contribution that is good enough to meet the daily needs of farmers (Ruhukail, 2012: 65). This can also be seen in the management of sago in the east Kolaka Regency. Its production activities include the management and processing of sago that has been passed down from generation to generation by their ancestors and is currently maintained and maintained by the sago farming community in the area.

East Kolaka Regency is one of the sago production areas in Indonesia where sago plantation areas are spread across several districts and villages. The East Kalimantan consists of 12 sub-districts and 8 subdistricts are sago-producing areas which include the districts of Tinondo, Tirawuta, Ueesi, Loea, Polipolia, Mowewe, Uluiwoi, and Ladongi. The total area of sago plantations in East Kalimantan is 801 hectares with a total number of farmers /planters of 1300 families (Department of Agriculture, 2016; BPS, 2016). The population of East Kolaka Regency is dominated by the Tolaki-Mekongga Tribe, which has the habit of sago consumption (sago consumption culture).

Production carried out by farmers is always based on the desire to maximize production and profits and minimize production costs. In general, farmers do a variety of ways to reduce costs and increase farm production. This is in line with the theory of production, namely maximizing production and maximizing profits (Benjamin, 2012; 108). In general, production is defined as an activity or process that transforms inputs into outputs (Assauri, 2008; 17).

The description of problems in managing sago in East Kalimantan in production activities can be seen in the presence of some of the sago farmers who make sago management no longer a major activity because these farmers have started to switch professions by cultivating other more productive plants in a short time. More and fewer sago farmers are allocating their time for the management of their sago orchards so that more and more sago gardens are left untreated and neglected. Then, sago farmers in several villages in East Kalimantan did not develop semi-cultural sago (intentionally planted sago clumps).

Furthermore, in terms of sago starch processing and production equipment used by sago farmers in East Kalimantan, it can be seen that it still uses traditional methods in its processing when compared to the sago starch processing carried out by sago farmers in other regions which are more advanced and developed because according Mosher (1991: 96) that technology that is constantly changing and developing is one of the basic requirements of agricultural development. Then sago farmers in East Kalimantan have not been able to develop sago into other products. So far, it has only been processed into starch (wet sago), local snacks (bagea), and utilizing sago leaves for roofing, even though in other areas sago has been developed 
into many products in the following current industrial needs.

Based on the above explanations, the research on the study of production and productivity of sago plants in East Kolaka Regency is important to do because of the direction and the ultimate goal for the sustainability of sago farming in sustaining the future in terms of sago food needs and in order to improve the lives of sago farmers, especially to improve the environment in Indonesia. As we know that production is very determining the sustainability of sago. The purpose of this study was to examine the production and productivity of sago plants in East Kolaka.

\section{RESEARCH METHODS}

The study was conducted in 14 villages in East Kolaka Regency, Southeast Sulawesi Province in April August 2018. The unit of analysis of this study was sago farmers and households that had sago plants in East Kolaka Regency (Koltim). Sago farmers are spread in 14 villages (8 sub-districts) in East Kolaka Regency, Southeast Sulawesi Province, Indonesia, which is the center of sago production. From each village randomly selected sample households whose sample size has been determined based on the Slovin formula with a confidence level of $95 \%$ to obtain a sample of 203 people from a population of 412 sago farmer households. The research approach used is a quantitative approach that uses primary data and secondary data with a combination of quantitative and qualitative methods both in data collection and analysis. The variant of methods used in this study is survey methods (research using questionnaires and samples as the main data collection tool). Analysis of the data that will be used in research is quantitative and qualitative descriptive analysis.

\section{RESULTS AND DISCUSSION}

CHARACTERISTICS OF SAGO FARMERS IN EAST KOLAKA

\section{Age and Education Level}

The age of sago farmers in each of the sample villages in East Kolaka Regency varies greatly, ranging from 30-70 years with an average age of 50 years. The distribution of sago farmers by age group in 14 villages can be seen in the following table.

Table 1. Distribution of sago farmers various age groups, 2018

\begin{tabular}{|c|c|c|c|c|c|c|c|c|c|c|c|c|c|c|c|c|}
\hline \multirow{2}{*}{$\begin{array}{c}\text { Age } \\
\text { category } \\
\text { (year) }\end{array}$} & \multicolumn{16}{|c|}{ Village } \\
\hline & $\begin{array}{l}\text { Poli- } \\
\text { polia }\end{array}$ & $\begin{array}{l}\text { Poni- } \\
\text { poniki }\end{array}$ & $\begin{array}{c}\text { Simbune } \\
\text { (3) }\end{array}$ & $\begin{array}{c}\text { Tinengi } \\
\text { (4) }\end{array}$ & $\begin{array}{c}\text { Lalowura } \\
\text { (5) }\end{array}$ & $\begin{array}{c}\text { Loea } \\
(6)\end{array}$ & $\begin{array}{c}\text { Simbalai } \\
(7)\end{array}$ & $\begin{array}{l}\text { Ladongi } \\
\text { (8) }\end{array}$ & $\begin{array}{l}\text { Puuoso } \\
\text { (9) }\end{array}$ & $\begin{array}{c}\text { Alaaha } \\
(10)\end{array}$ & $\begin{array}{l}\text { Ueesi } \\
\text { (11) }\end{array}$ & Silui (12) & \begin{tabular}{|c} 
Ueete \\
(13)
\end{tabular} & $\begin{array}{c}\text { Aukora } \\
\text { (14) }\end{array}$ & Total & $\begin{array}{c}\text { Pecentages } \\
(\%)\end{array}$ \\
\hline $30-45$ & 6 & 6 & 14 & 0 & 0 & 3 & 7 & 3 & 2 & 3 & 1 & 1 & 4 & 5 & 53 & 26,11 \\
\hline $46-60$ & 14 & 10 & 14 & 7 & 3 & 11 & 20 & 3 & 9 & 10 & 3 & 5 & 12 & 8 & 130 & 64,04 \\
\hline $61-75$ & 1 & 1 & 1 & 1 & 3 & 0 & 3 & 2 & 2 & 3 & 0 & 0 & 2 & 1 & 20 & 9,85 \\
\hline Total & 21 & 17 & 29 & 8 & 6 & 14 & 30 & 8 & 13 & 16 & 4 & 7 & 18 & 12 & 203 & 100 \\
\hline
\end{tabular}

Source: Research Results, 2018

Sago farmers are the most dominant age group in the age group 46-60 years and only a small proportion are in the age group 61-75 years. This indicates that sago farmers in general in East Kolaka are still in the productive age to work. 
Furthermore, the level of education of sago farmers in East Kolaka Regency also varies from elementary to tertiary level. The distribution of the sago farmer education level can be seen in the table below.

Table 2. Distribution of sago farmers in various education level, 2018

\begin{tabular}{|c|c|c|c|c|c|c|c|c|c|c|c|c|c|c|c|c|}
\hline \multirow[b]{2}{*}{$\begin{array}{l}\text { Level of } \\
\text { education }\end{array}$} & \multicolumn{16}{|c|}{ Village } \\
\hline & $\begin{array}{c}\text { Poli- } \\
\text { polia } \\
\text { (1) }\end{array}$ & $\begin{array}{l}\text { Poni- } \\
\text { poniki } \\
\text { (2) }\end{array}$ & $\begin{array}{c}\text { Simbune } \\
\text { (3) }\end{array}$ & $\begin{array}{l}\text { Tinengi } \\
\text { (4) }\end{array}$ & $\begin{array}{l}\text { Lalowura } \\
\text { (5) }\end{array}$ & \begin{tabular}{|c|} 
Loea \\
$(6)$
\end{tabular} & $\begin{array}{c}\text { Simbalai } \\
(7)\end{array}$ & $\begin{array}{l}\text { Ladongi } \\
\text { (8) }\end{array}$ & $\begin{array}{l}\text { Puuoso } \\
\text { (9) }\end{array}$ & $\begin{array}{c}\text { Alaaha } \\
\text { (10) }\end{array}$ & \begin{tabular}{|c|} 
Ueesi \\
(11)
\end{tabular} & Silui (12) & $\begin{array}{l}\text { Ueete } \\
\text { (13) }\end{array}$ & $\begin{array}{l}\text { Aukora } \\
\text { (14) }\end{array}$ & Total & $\begin{array}{c}\text { Pecentages } \\
(\%)\end{array}$ \\
\hline SD & 1 & 1 & 1 & 0 & 1 & 0 & 0 & 0 & 0 & 0 & 0 & 1 & 0 & 0 & 5 & 2,46 \\
\hline SLTP & 2 & 4 & 9 & 1 & 0 & 0 & 3 & 2 & 3 & 3 & 0 & 0 & 4 & 0 & 31 & 15,27 \\
\hline SLTA & 17 & 10 & 16 & 7 & 5 & 13 & 27 & 6 & 10 & 13 & 4 & 5 & 14 & 12 & 159 & 78,33 \\
\hline PT & 1 & 2 & 3 & 0 & 0 & 1 & 0 & 0 & 0 & 0 & 0 & 1 & 0 & 0 & 8 & 3,94 \\
\hline Total & 21 & 17 & 29 & 8 & 6 & 14 & 30 & 8 & 13 & 16 & 4 & 7 & 18 & 12 & 203 & 100 \\
\hline
\end{tabular}

Source: Research Results, 2018

Based on the table above it can be seen that the education level of the sago farmer who is the most dominant is at the high school education level, which is $78.33 \%$ because the educational falsity in East Kolaka is quite adequate. While the elementary education level has the smallest amount of $2.46 \%$. Similarly, farmers who have a college-level education are still relatively few.

\section{Number of Household Members}

Table 3. Distribution of Sago Farmer Household Members in 14 Villages in East Kolaka Dsitrict, 2018

\begin{tabular}{|c|c|c|c|c|c|c|c|c|c|c|c|c|c|c|c|c|}
\hline \multirow[b]{2}{*}{$\begin{array}{c}\text { The number } \\
\text { of household } \\
\text { members }\end{array}$} & \multicolumn{16}{|c|}{ Village } \\
\hline & $\begin{array}{c}\text { Poli-polia } \\
\text { (1) }\end{array}$ & $\begin{array}{l}\text { Poni- } \\
\text { poniki }\end{array}$ & $\begin{array}{l}\text { Simbune } \\
\text { (3) }\end{array}$ & $\begin{array}{l}\text { Tinengi } \\
\text { (4) }\end{array}$ & $\begin{array}{l}\text { Lalowura } \\
\text { (5) }\end{array}$ & \begin{tabular}{|c|} 
Loea \\
$(6)$
\end{tabular} & $\begin{array}{c}\text { Simbalai } \\
\text { (7) }\end{array}$ & $\begin{array}{l}\text { Ladongi } \\
\text { (8) }\end{array}$ & Punoso (9) & $\begin{array}{c}\text { Alaaha } \\
\text { (10) }\end{array}$ & \begin{tabular}{|c|} 
Ueesi \\
$(11)$
\end{tabular} & Silui (12) & $\begin{array}{l}\text { Ueete } \\
(13)\end{array}$ & $\begin{array}{c}\text { Aukora } \\
\text { (14) }\end{array}$ & Total & Pecentages (\%) \\
\hline $1-2$ & 0 & 1 & 0 & 0 & 0 & 0 & 1 & 1 & 1 & 0 & 0 & 0 & 0 & 0 & 4 & 1,97 \\
\hline $3-4$ & 13 & 6 & 11 & 4 & 1 & 5 & 8 & 4 & 7 & 7 & 2 & 6 & 8 & 4 & 86 & 42,36 \\
\hline $5-6$ & 7 & 9 & 18 & 4 & 4 & 9 & 16 & 3 & 5 & 8 & 2 & 1 & 9 & 6 & 101 & 49,75 \\
\hline$>6$ & 1 & 1 & 0 & 0 & 1 & 0 & 5 & 0 & 0 & 1 & 0 & 0 & 1 & 2 & 12 & 5,91 \\
\hline Total & 21 & 17 & 29 & 8 & 6 & 14 & 30 & 8 & 13 & 16 & 4 & 7 & 18 & 12 & 203 & 100 \\
\hline
\end{tabular}

Source: Research Results, 2018

Based on the table above shows that $49.75 \%$ of farmer's household members are 5-6 people, while $42.36 \%$ of farmers who have 3-4 household members. A large number of farmer household members is due
The number of household members of sago farmers in 14 villages in East Kolaka Regency varies from 2 to 8 people. According to Sayogyo (1996) in Bulkis (2012) stated that the small number of household members will facilitate the improvement of welfare, fulfillment of food and household clothing and education. To find out the distribution of the number of sago farmer household members, see the following table. 


\section{Sago Farmer Jobs}

Based on direct observations at the research location, the types of work in 14 sample villages in East Kolaka

Table 4. Distribution of Farmers Based on job in 14 villages, 2018
Regency can be identified which can be seen in the table below.

\begin{tabular}{|c|c|c|c|c|c|c|c|c|c|c|c|c|c|c|c|c|c|c|c|c|c|c|c|c|c|c|c|c|c|c|c|c|}
\hline \multirow{3}{*}{ Job } & \multicolumn{28}{|c|}{ Villages } & \multirow{2}{*}{\multicolumn{2}{|c|}{ Total }} & \multirow{2}{*}{\multicolumn{2}{|c|}{$\begin{array}{c}\text { Percentage } \\
\mathbf{s}(\%)\end{array}$}} \\
\hline & \multicolumn{2}{|c|}{ Poli-polia } & \multicolumn{2}{|c|}{$\begin{array}{l}\text { Poni- } \\
\text { poniki }\end{array}$} & \multicolumn{2}{|c|}{ Simbune } & \multicolumn{2}{|c|}{ Tinengi } & \multicolumn{2}{|c|}{ Lalowura } & \multicolumn{2}{|c|}{ Loea } & \multicolumn{2}{|c|}{ Simbalai } & \multicolumn{2}{|c|}{ Ladongi } & \multicolumn{2}{|c|}{ Puuosu } & \multicolumn{2}{|c|}{ Alaaha } & \multicolumn{2}{|c|}{ Ueesi } & \multicolumn{2}{|c|}{ Silui } & \multicolumn{2}{|c|}{ Ueete } & \multicolumn{2}{|c|}{ Aukora } & & & & \\
\hline & U & s & U & s & U & S & U & S & U & S & U & S & U & $\mathrm{s}$ & U & $s$ & U & $s$ & U & $s$ & U & s & U & $s$ & U & $\mathrm{s}$ & U & $s$ & $\mathrm{U}$ & $\mathrm{s}$ & $U$ & $\mathrm{~s}$ \\
\hline Farmer & 18 & 3 & 13 & 4 & 23 & 6 & 6 & 2 & 5 & 1 & 10 & 4 & 22 & 8 & 5 & 3 & 9 & 4 & 12 & 4 & 3 & 1 & 5 & 2 & 14 & 4 & 8 & 4 & 153 & 50 & 75.37 & 98.04 \\
\hline Civil Servant & 2 & 1 & 0 & 0 & 0 & 0 & 1 & 0 & 0 & 0 & 0 & 0 & 4 & 0 & 0 & 0 & 0 & 0 & 0 & 0 & 0 & 0 & 0 & 0 & 0 & 0 & 1 & 0 & 8 & 1 & 3.94 & 1.96 \\
\hline Enterpreneur & 1 & 0 & 4 & 0 & 6 & 0 & 1 & 0 & 1 & 0 & 4 & 0 & 4 & 0 & 3 & 0 & 4 & 0 & 4 & 0 & 1 & 0 & 2 & 0 & 4 & 0 & 3 & 0 & 42 & 0 & 20.69 & 0.00 \\
\hline Total & 21 & 4 & 17 & 4 & 29 & 6 & 8 & 2 & 6 & 1 & 14 & 4 & 30 & 8 & 8 & 3 & 13 & 4 & 16 & 4 & 4 & 1 & 7 & 2 & 18 & 4 & 12 & 4 & 203 & 51 & 100 & 100 \\
\hline
\end{tabular}

Source: Research Results, 2018

Based on the table above shows that farmers are the most dominant main occupation in 14 sample villages, which is around $75.37 \%$, while $24.6 \%$ of the sample makes farmers as a side job.

\section{Production and productivity of sago plants in East Kolaka District}

Sago is a source of food for indigenous people in the east Kolaka Regency (Koltim). This plant is often found in some gardens owned by residents of the region. In this area, sago is called tawaro. Sago is processed into a staple food called sinonggi. Sago plants live in colonies to form a colony called a clump. In one family there are on average 21 sago tillers. Based on the data we obtained in the field, it is known that each farmer has an average of \pm 14 trees ready for harvest in his sago groves. While the number of sago flour production in each tree is \pm 21 basong (sacks).

Sago processing (masumaku tawaro) is one of the sources of livelihood in 14 villages in East Kolaka that provides income and contributes to meet the daily needs of farmers in this area. But sago is an annual plant. Therefore, farmers are required to wait about 5-7 years to be able to carry out harvesting and processing activities to become products that can be consumed. So farmers cannot hang their lives completely on sago processing activities as their main source of livelihood. However, farmers must cultivate and cultivate other plants that can provide profits in a short time while waiting for the sago harvest. The phenomenon that occurs in East Kalimantan is that sago processing has been carried out by their ancestors and is currently maintained and maintained by the sago farming community in the area. Production carried out by farmers is always based on the desire to maximize production and profits and minimize production costs. In general, farmers use various methods to reduce costs and increase production.

As basic sago can be processed or produced into a variety of products of use-value. There have been many areas that have become centers of sago plants in Indonesia, including Papua, Ambon, Riau Islands, South Sulawesi, and so on. They have developed various sago products, such as various traditional snacks, sago noodles, dried starch and products that can have a longer shelf life than if it is produced into wet sago. However, at present, the sago plant in East Kolaka Regency is only limited to wet starch which is packaged in sacks and then marketed to retailers in the market and large traders that will be distributed to other regions. Sago production in the East Kalimantan regency varies from region to region. Sago production spread in 14 villages in East Kalimantan can be seen in Table 5. 
Table 5. Production and productivity of sago plants in East Kalimantan

\begin{tabular}{|c|c|c|c|c|c|c|}
\hline \multirow{2}{*}{$\begin{array}{l}\text { Num } \\
\text { ber }\end{array}$} & \multirow{2}{*}{$\begin{array}{c}\text { Villag } \\
\text { e }\end{array}$} & \multicolumn{2}{|c|}{$\begin{array}{c}\text { Average } \\
\text { production } \\
\text { in a year }\end{array}$} & \multirow{2}{*}{$\begin{array}{l}\text { Average } \\
\text { land } \\
\text { area of } \\
\text { sago } \\
\text { (ha) }\end{array}$} & \multicolumn{2}{|c|}{$\begin{array}{c}\text { Average } \\
\text { Productivity }\end{array}$} \\
\hline & & $\begin{array}{c}\text { (sack } \\
/ \text { yr })\end{array}$ & $\begin{array}{l}\mathbf{k g} \\
/ \mathbf{y r} \\
)\end{array}$ & & $\begin{array}{l}\text { (sack } \\
/ \text { yr })\end{array}$ & $\begin{array}{l}\text { (ton/ } \\
\text { thn) }\end{array}$ \\
\hline 1 & $\begin{array}{l}\text { Poli- } \\
\text { polia } \\
\text { poni- }\end{array}$ & 177 & $\begin{array}{r}3,2 \\
24 \\
6,6\end{array}$ & 0.7 & 4,646 & 4.6 \\
\hline 2 & $\begin{array}{l}\text { poniki } \\
\text { Simbu }\end{array}$ & 363 & $\begin{array}{r}06 \\
3,2\end{array}$ & 0.9 & 7,141 & 7.1 \\
\hline 3 & $\begin{array}{l}\text { ne } \\
\text { Tineng }\end{array}$ & 180 & $\begin{array}{r}76 \\
6,0\end{array}$ & 0.6 & 5,541 & 5.5 \\
\hline 4 & $\begin{array}{l}\text { i } \\
\text { Lalow }\end{array}$ & 331 & $\begin{array}{r}29 \\
3,0\end{array}$ & 0.8 & 7,377 & 7.4 \\
\hline 5 & ura & 167 & $\begin{array}{r}33 \\
6,2\end{array}$ & 0.6 & 5,527 & 5.5 \\
\hline 6 & $\begin{array}{l}\text { Loea } \\
\text { Simbal }\end{array}$ & 344 & $\begin{array}{r}53 \\
2,8\end{array}$ & 1.1 & 6,276 & 6.3 \\
\hline 7 & $\begin{array}{l}\text { ai } \\
\text { Ladon }\end{array}$ & 158 & $\begin{array}{r}82 \\
2,1\end{array}$ & 0.8 & 3,849 & 3.8 \\
\hline 8 & gi & 119 & $\begin{array}{r}61 \\
4,0\end{array}$ & 0.9 & 2,475 & 2.5 \\
\hline 9 & Puuosu & 223 & $\begin{array}{r}60 \\
5,0\end{array}$ & 0.6 & 5,835 & 5.8 \\
\hline 10 & Alaaha & 279 & $\begin{array}{r}85 \\
3,7\end{array}$ & 0.7 & 7,724 & 7.7 \\
\hline 11 & Ueesi & 208 & $\begin{array}{r}77 \\
4,3\end{array}$ & 0.8 & 4,709 & 4.7 \\
\hline 12 & Silui & 239 & $\begin{array}{r}42 \\
5,6\end{array}$ & 1.0 & 4,917 & 4.9 \\
\hline 14 & $\begin{array}{l}\text { Ueete } \\
\text { Aukor } \\
\text { a }\end{array}$ & 311 & $\begin{array}{r}62 \\
3,6 \\
40\end{array}$ & 0.8 & 7,460 & 7.5 \\
\hline $\mathrm{A}$ & & 236 & $\begin{array}{r}4,2 \\
88\end{array}$ & 1 & 5,642 & 5.6 \\
\hline
\end{tabular}

Source: Research Results, 2018

Based on the results of the study in Table 5 shows that the average production in each year in the 14 villages ranges from 119 sacks/year - 363 sacks/year or equivalent to $2,161 \mathrm{~kg} / \mathrm{yr}-6,606 \mathrm{~kg} / \mathrm{yr}$. The processing of sago stems to become wet starch (tawaro) for each sago farmer is different in number each year because many of the sago starches are greatly influenced by the proper harvesting period and the habitat conditions in which sago trees grow. The amount of production ranges from 1 to 3 times a month adjusted to the stock of ready-to-harvest sago trees owned by sago farmers. The highest average sago starch production is in the Poniponiki village, which is $6,606 \mathrm{~kg} / \mathrm{yr}$. This is because sago plantations in Poniponiki are still numerous and are spread almost in every farmer farm. Besides that, the activity of sago consumption in Simbalai is still thick because the native inhabitants of Tolaki Mekek still dominate the area. While the lowest production is in Ladongi village, which is $2,161 \mathrm{~kg} / \mathrm{yr}$, this is because sago plantations have been largely converted into paddy fields and some are used as settlements. The average productivity of sago trees in one hectare in East Kolaka looks varied in 14 villages. The highest productivity was found in Alaaha village, which was 7.7 tons/ha/yr while the lowest productivity was 2.5 tons/ha/yr in Ladongi village. Sago crop productivity in East Kalimantan shows quite good productivity because according to Flach (1980) in Harsanto (1986: 18-19) that for sago cropping conditions that have not been properly cultivated have a productivity of 2.5 tons/ha/yr while for sago cropping after technology to improve sago plants through technical improvements in planting will produce productivity of 10 tons/ha/year. This shows that when sago plantations are used in the improvement of sago plant technology in East Kalimantan, they will provide products that is much higher than today.

\section{IV.CONCLUSION}

Based on the results of research conducted it can be concluded as follows:

1. Production in each year in the 14 villages ranges from 119 sacks/year - 363 sacks/year or equivalent to $2,161 \mathrm{~kg} / \mathrm{yr}-6,606 \mathrm{~kg} / \mathrm{yr}$. The highest average sago starch production is in the Poniponiki village, which is $6,606 \mathrm{~kg} / \mathrm{yr}$. While the lowest production is in the Ladongi village, $2,161 \mathrm{~kg} / \mathrm{yr}$.

2. The highest productivity is found in Alaaha village, which is 7.7 tons/ha/yr while the lowest 
productivity is 2.5 tons/ha/yr in Ladongi village. Sago plant productivity in East Kolaka District shows quite good productivity for the condition of sago cultivation that is still extractive by naturally

\section{REFERENCES}

[1]. Assauri, S. 2008. Manajemen Produksi dan Operasi. Edisi Revisi. Lembaga Penerbit Fakultas Ekonomi Universitas Indonesia. Jakarta.

[2]. Barlina, Rindengan dan Karouw, Steivie. 2003. Potensi pati sagu sebagai bahan baku plastik. Prosiding Seminar Nasional Sagu. Pusat penelitian dan Pengembangan Perkebunan. Bogor.

[3]. Benyamin, I.M. Teori Konsumsi dan Produksi. 2012. CV. Multi Global Makassar. Hal 57 ; 108

[4]. Bintoro, M.H., M.Y.J. Purwanto dan S. Amarillis, 2010. Sagu di Lahan Gambut. IPB Bogor.

[5]. Haryanto, B., dan H. Henanto. 2003. Teknologi Pengolahan Lanjut pati Sagu untuk menghasilkan produk komersil. Prosiding Seminar Nasional Sagu. Pusat penelitian dan Pengembangan Perkebunan Bogor

[6]. Ibrahim. K, dan Gunawan H. 2015. dampak kebijakan konversi lahan sagu sebagai upaya mendukung program pengembangan padi sawah di kabupaten Halmahera Barat Maluku utara. PROS SEM MASY BIODIV INDON I (5) ; 10641074 DOI: $10.13057 / \mathrm{psnmbi} / \mathrm{m} 010517$ diakses 20 November 2017

[7]. Juwita, Dian. Ayu, Suharti. Netty, Rasyid. Roslinda. 2013. Isolasi Jamur Pengurai Pati Dari Tanah Limbah Sagu. Jurnal Farmasi Andalas Vol 1 (1) April 2013. ISSN : 2302-8254 / 35

[8]. Jong, F.S. 2018. An overview of sago industry development, 1980s-2015. Sago Palm. Springer Open. https://doi.org/10.1007/978-981-10-52699_6 diakses 10 Desember 2018

[9]. Mosher, A.T. 1991. Menggerakkan dan membangun pertanian. Cetakan ke-13. CV Yasaguna
[10]. Nguyen., Trung Thanh , Truong Lam Do, Priyanka Parvathi, Ada Wossink and Ulrike Grote. 2017. Farm production efficiency and natural forest extraction : Evidence from Cambodia. Land Use Policy : 1 diakses 12 Desember 2017

[11]. Novarianto, Hengky. 2003. Pengembangan sagu semi budidaya.Pusat penelitian dan pengembangan Perkebuanan. Prosiding Seminar nasional Sagu. : 36 -38. Bogor

[12]. Ruhukail. N.L. 2012. karakteristik petani sagu dan keragaman serta manfaat ekonomi sagu bagi masyarakat dusun waipaliti desa Hitu Kecamatan Leihitu Kabupaten Maluku tengah. Jurnal Agroforestry VII (1) : 65-72

[13]. Singhal. Rekha S., Kennedy. John F., Sajilata M, Gopalakrishnan, Kaczmarek. Agnieszka., Knill. Charles. J and Akmar. Putri Faridatul. 2008. Industiral production, processing, and utilization of sago palm-derived products. Carbohydrate Polymers. diakses 11 Desember 2017

[14]. Suriani, A. Aziz. 2002. Sago Starch and utilization. journal of bioscience and bioengeneering Vol. 94, No. 6, 526529.2002

[15]. Syakir, M and E. Karmawati. 2013. Potensi Tanaman Sagu (Metroxylon spp.) Sebagai Bahan Baku Bioenergi. Perspektif Vol.22. No.2 ; 57-64

[16]. Taridala. Sitti Aida Adha, Jusof. Kamaruzaman, Zani. Munirman, Abdullah. Weka Gusmiaty, Suriana, Merdekawati. Ika. 2013. Supply chain in sago Agribusiness. Science Journal 26: 7 diakses 10 Desember 2017

\section{Cite this article as :}

Asthutiirundu, Sitti Bulkis, Imam Mujahidin, M. H. Jamil, "Study of Production and Productivity of Sago Plant in East Kolaka District, Southeast Sulawesi Province, Indonesia", International Journal of Scientific Research in Science and Technology (IJSRST), Online ISSN : 2395602X, Print ISSN : 2395-6011, Volume 6 Issue 5, pp. 259265, September-October 2019. Available at doi : https://doi.org/10.32628/IJSRST196531 Journal URL : http://ijsrst.com/IJSRST196531 